\title{
EFFECT OF TRACE ELEMENT SUPPLEMENTATION ON THE GASTROINTESTINAL PARASITES OF GRAZING SHEEP
}

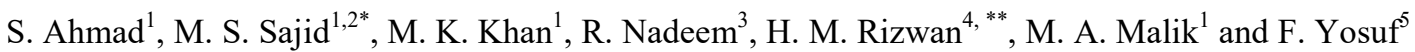 \\ ${ }^{1}$ Department of Parasitology, ${ }^{2}$ One Health Lab. Center for Advanced Studies, ${ }^{3}$ Department of Chemistry, University of \\ Agriculture, Faisalabad, Pakistan, ${ }^{4}$ Section of Parasitology, Department of Pathobiology, College of Veterinary and \\ Animal Science, Narowal, Sub-campus UVAS, Lahore, Pakistan, ${ }^{5}$ Veterinary Research Institute, Lahore, Punjab, \\ Pakistan \\ *Corresponding Author's E-mail: drsohailuaf@hotmail.com;**hm.rizwan@uvas.edu.pk
}

https://doi.org/10.36899/JAPS.2020.1.0009

Published online January 02, 2020

\begin{abstract}
Alternative gastrointestinal (GI) parasite control strategies including phytomineral/ trace-element supplementation have gained currency in preview of anthelmintic resistance in the grazing sheep. This paper reports an association of the selected plants/ forages having optimum levels of Zinc ( $\mathrm{Zn}$ ), Copper (Cu), Manganese (Mn) and Cobalt (Co) on the GI parasitic burden in sheep and hence on the productive performance of the grazing sheep of Multan district, Punjab, Pakistan. To this end, levels of trace elements were determined in the plants/ forages preferred by the grazing sheep, and in the sera of randomly selected grazing sheep $(n=384)$. Serum trace element profile was correlated with the GI parasitic burden to determine the possible impact of trace-elements on GI parasitic load. After pre-treatment, wet digestion of sera and plants, concentration of the selected minerals $(\mathrm{Cu}, \mathrm{Co}, \mathrm{Zn}$ and $\mathrm{Mn})$ were measured using spectrophotometry. Faecal samples $(\mathrm{n}=384)$ were subjected to the quantitative faecal examination using McMaster technique. Overall $42.44 \%$ prevalence of GI parasites was found in the study population. Of the eight screened forages, Cynodon dactylon, Launaea nudicaulis and Digitaria sanguinalis showed top three levels of $\mathrm{Mn}$ in decreasing order. Comparative mineral profile of sera was significantly different among the four tehsils (administrative units) of Multan district, Punjab, Pakistan. Mn showed significant correlation with the egg per gram (EPG) of faeces in sheep of tehsil Shujabad, whereas, $\mathrm{Cu}, \mathrm{Zn}$ and Co showed insignificant results in all tehsils of Multan district. Further research is needed to explain the possible mechanism involved in the role of $\mathrm{Mn}$ in the indirect resilience of animals against the GI parasites. These forages might be preferred as holistic approach and possible use as a preventive management of GI parasitism in grazing sheep of the country.
\end{abstract}

Keywords: Multan; Sheep; Forages; Gastrointestinal parasitism; Phytominerals; Sera samples, Trace elements.

\section{INTRODUCTION}

Sheep (Ovis aries) is reared for wool, skins, mutton and milk in the small holder farming systems of Pakistan. Its significance has increased manifolds in the view of its use as sacrificial animals in the Muslim Community (Rizwan et al., 2019a). Due to compromised management of livestock in resource-poor countries, there is always a threat of parasitic infestation in livestock leading to marginal productivity (Kumar et al., 2013). Generally, parasitism is diagnosed through clinical signs and/or microscopic examination and is treated by anthelmintics like levamisole, triclabendazole, oxyclozanide and oxfendazole etc (Khan et al., 2017). There are certain limitations of anthelmintics including development of resistance and presence of drug residues which cause health problems in humans (Wolstenholme et al., 2004). To overcome these hazards, alternative sources for example, ethnoveterinary medicine or plants having anthelmintic properties are recommended
(Gathuma et al., 2004; Mahima et al., 2012; Tiwari et al., 2018).

Nature has blessed the rangelands of our country with a diversified nature of grazing forages which are enriched with trace elements (Khan et al., 2005). Trace elements deficiencies or imbalances in livestock are world-wide problem particularly in grazing sheep (Samanta \& Samanta, 2002; Qudoos et al., 2017; Rizwan et al., 2019). Generally, trace elements play an imperative role in disease resistance (Yatoo et al., 2013) by activation of the enzyme system. Trace elements including Zinc ( $\mathrm{Zn})$, Copper ( $\mathrm{Cu})$, Manganese $(\mathrm{Mn})$ and Cobalt $(\mathrm{Co})$ are important for the normal immune function and disease resistance (Radostits et al., 2007). The basic concept takes into the anthelmintic effects of trace element is still unclear. However, improved mineral levels in animals' sera have showed significant reduction of parasitic infection (Yatoo et al., 2013; Rizwan et al., 2019).

Trace elements are parts of various tissues and work as cofactors for various enzymes (Erdoğan et al., 
2002, Anonymous, 2016). Low levels of trace element in animals reduce the immune function which ultimately increases the chances of parasitic infection (McClure, 2008). Aypak et al. (2016) concluded that $\mathrm{Cd}$ had significant association with the gastrointestinal (GI) parasites; however, others including $\mathrm{Ca}, \mathrm{P}, \mathrm{Mg}, \mathrm{Fe}, \mathrm{Cu}$, $\mathrm{Zn}, \mathrm{Mn}, \mathrm{Ni}$ were insignificant. Later Qudoos et al., (2017) found insignificant association of all trace elements $(\mathrm{Cu}, \mathrm{Mo}, \mathrm{Se}, \mathrm{Zn}, \mathrm{Mn}, \mathrm{Co})$ with egg per gram (EPG) of naturally infected sheep population of Chakwal district. Recently, Rizwan et al. (2019) reported that sheep having high levels of $\mathrm{Zn}$ and $\mathrm{Cu}$ in serum showed lower burdens of GI parasites.

Investigations to assess the current status of different minerals in the indigenous forages, and animals in association with the GI parasites is hence, justified. This paper is in continuation with the earlier studies which presents the prevalence of GI parasites and trace elements $(\mathrm{Co}, \mathrm{Cu}, \mathrm{Mn}, \mathrm{Zn})$ profile of the grazing sheep population of Multan district as well as their levels in corresponding forages. Furthermore, correlation of trace mineral profile of sheep sera with GI parasitic burden was established.

\section{MATERIALS AND METHODS}

Sample collection: District Multan (30 $10^{\circ} 44^{\prime \prime} \mathrm{N} / 71^{\circ}$ 28'31" E) consists of four administrative divisions (tehsils) namely; (a) Multan city, (b) Multan Saddar, (c) Shujaabad and (d) Jalalpur Pirwala. Estimating 50\% value of expected prevalence, a total of 384 sheep $(85$ from Multan city, 81 from Multan Saddar, 118 from Shujaabad and 100 from Jalalpur Pirwala) at 95\% confidence interval were randomly selected during spring season from different sites of the study district. Faecal samples were collected using standard protocols given by Soulsby (1982). The blood samples $(5 \mathrm{~mL})$ were collected from the selected sheep in a gel clot activator vacutainer and labeled properly. Two grazing sites (at the distance of $15 \mathrm{Km}$ ) were selected from each tehsil of the study district for collection of a total of eight forages in zip-lock polyethene bags. Samples were transported to the Department of Parasitology, University of Agriculture, Faisalabad (UAF), Pakistan.

Coprological examination: The collected faecal samples were processed through McMaster technique for quantitative examination (Soulsby, 1982). Briefly, three grams of faeces were mixed with $45 \mathrm{~mL}$ concentrated $\mathrm{NaCl}$. The suspension was strained through a tea strainer, filled into the McMaster egg counting chambers, and examined under compound microscope to count eggs for calculation of eggs per gram of faeces. Eggs were identified by ova identification keys (Soulsby, 1982) and micrometry.

\section{Pre-treatment of samples for elemental analysis:}

Sera: Following centrifugation, sera were transferred into Eppendorf tubes using a Pasteur's pipette and stored at $-30^{\circ} \mathrm{C}$ till further use. Sera were subjected to wet digestion following the method reported by Bhushan et al. (2010). Briefly, one $\mathrm{mL}$ serum was taken into a digestion flask and mixed with $10 \mathrm{~mL}$ of concentrated $\mathrm{HNO}_{3}$. Then, Mixture was heated at $60-70^{\circ} \mathrm{C}$ for 15 minutes followed by its cooling and addition of $\mathrm{HClO}_{4}(5$ $\mathrm{mL})$. The contents of the flask were heated vigorously till the volume reduced to $1-2 \mathrm{~mL}$ and diluted up to $25 \mathrm{~mL}$ by adding deionized water.

Forages: The forages were identified by expert botanists from the Department of Botany, UAF before their further processing. The leaves of the collected plants were washed with $1 \% \mathrm{HCl}$, then with distilled water followed by air drying. Air-dried samples were dried in drying oven $\left(65 \pm 5^{\circ} \mathrm{C}\right)$ and ground to powder. Dried plant samples (one gram each) were taken in a volumetric flask and kept overnight after adding concentrated $\mathrm{HNO}_{3}(5$ $\mathrm{mL})$ and $\mathrm{HClO}_{4}(5 \mathrm{~mL})$ in each sample. Next day, concentrated $\mathrm{HNO}_{3}(5 \mathrm{~mL})$ was added in each sample and digestion was done on a hot plate till material became clear. After its cooling, the volume was made up to 25 $\mathrm{mL}$ using de-ionized water (Miller et al., 1998), filtered through Whatman filter No. 42 and stored in air tight bottles for determination of mineral profile.

Atomic absorption spectrophotometry: Concentration of $\mathrm{Cu}, \mathrm{Co}, \mathrm{Mn}$ and $\mathrm{Zn}$ from the digested sera and forage samples were analyzed in triplicates with Atomic Absorption Spectrophotometer (AAS) following the conditions described by Radostits et al., (2007).

Statistical analyses: Prevalence of parasites with respect to variables (location, host species, sex and age group) were explored using Chi-square test. Analysis of variance (ANOVA) was used for determination of differences in trace elements profile of sera and forages. Association of trace elements of serum with burden of GI parasites was determined by Pearson's correlation method. P-values of less than 0.05 was considered significant, statistically (Schork and Remington, 2010). All the statistical tests were applied using Minitabe 17 software.

\section{RESULTS}

Prevalence of gastrointestinal parasites: The overall prevalence of GI parasites was $42.44 \%$ being highest $(47.45 \%$; 56/118) in Shujabad, followed in order by Multan city (45.88\%; 39/85), Jalalpur Pirwala (38\%; $38 / 100)$ and Multan Saddar $(37.04 \% ; 30 / 81)$. Over all prevalence of GI parasites in female $(49.00 \%)$ sheep was higher than male $(30.37 \%)$ in district Multan. Similarly, adults $(46.12 \%)$ showed higher prevalence as compared to young stock $(34.92 \%)$. The highest prevalence of GI parasites was observed in Thalli breed $(46.30 \%)$ followed in order by Kajli (42.52\%) and Buchi (35.79\%). Parasitic 
species identified from the microscopically scanned faecal samples were: Fasciola (F.) hepatica, F. gigantica, Haemonchus contortus, Eimeria crandallis, Oesophagostomum sp., Trichuris ovis, Strongyloides sp., Cryptosporidium sp. and Trichostrongylus sp. Eggs of $F$. hepatica and $F$. gigantica are operculated and similar in shape; however, eggs of $F$. hepatica are smaller $(150 \mu \mathrm{m}$ by $90 \mu \mathrm{m})$ than those of $F$. gigantica $(200 \mu \mathrm{m} \times 100 \mu \mathrm{m})$. The eggs of Haemonchus contortus are medium-sized (74 $\mu \mathrm{m} \times 44 \mu \mathrm{m})$ and numerous blastomeres nearly fill the entire egg. Oocysts of Eimeria crandallis are subspherical $(21.9 \mu \mathrm{m} \times 19.4 \mu \mathrm{m})$ with a micropylar cap. Eggs of Oesophagostomum spp. are $60 \mu \mathrm{m}-75 \mu \mathrm{m}$ while the eggs of Trichuris ovis are $75 \mu \mathrm{m} \times 35 \mu \mathrm{m}$ and an operculum at both ends. Strongyloides eggs are $20 \mu \mathrm{m}-$ $35 \mu \mathrm{m}$ and are larvated. Cryptosporidium oocysts are 5.0 $\mu \mathrm{m} \times 4.5 \mu \mathrm{m}$ and ovoidal or spheroidal in shape. Eggs of Trichostrongylus are $75 \mu \mathrm{m}-95 \mu \mathrm{m}$ in length. The animals' sex (female) and age (up to 6 months) were found to be significant while breed was found insignificant among all the tehsils of district Multan.

Forage species and their trace elements profile: Eight forages were preferably consumed by sheep in four tehsils of district Multan. The identified species included; Brachiaria raptens, Digitaria sanguinalis, Dactyloctenium aegyptium, Euphotia prostate, Cynodon dactylon, Launaea nudicaulis, Ziziphus mauritiana and Convuvulus arvensisa. Results of different trace element constituents of the identified forages are depicted in Table 1. Levels of $\mathrm{Zn}, \mathrm{Cu}, \mathrm{Mn}$ and Co were significantly $(\mathrm{P}<0.05)$ varied among the analyzed forages (Table 1). Maximum concentration of $\mathrm{Zn}$ was found in Ziziphus mauritianaand minimum in Launea nudicalis. Maximum and minimum concentrations of $\mathrm{Cu}$ were found in Cynodon dactylon and Convuvulus arvensisa, respectively. Cynodon dactylon and Brachiaria raptens contained maximum and minimum concentrations of $\mathrm{Mn}$, respectively. Concentration of $\mathrm{Co}$ was highest in Brachiaria raptens and lowest in Convuvulus arvensisa. Other plants had intermediate values of the respective trace minerals.

Mean concentration (conc.) of trace elements of forages collected from different tehsils of Multan district are depicted in Table 2. Variation in mean conc. of $\mathrm{Zn}$, $\mathrm{Cu}, \mathrm{Mn}$ and $\mathrm{Co}$ in forages from different tehsils was statistically insignificant $(\mathrm{P}>0.05)$. Forages located at tehsil Shujabad contained maximum conc. of $\mathrm{Zn}$ and forages from tehsil Multan Saddar contained minimum conc. Mean conc. of $\mathrm{Cu}$ in forages from tehsil Multan Saddar was maximum, whereas, it was minimum in forages from tehsil Jalalpur Pirwala. Maximum mean conc. of Mn was observed in forages from tehsil Multan City, while minimum in forages collected from tehsil Shujabad. Mean conc. of Co was maximum $(1.63 \pm 0.16$ $\mathrm{mg} / \mathrm{kg}$ ) in forages from tehsil Multan Saddar, while forages from tehsil Jalalpur Pirwala contained minimum conc.

Trace elements profile of sheep serum: Results of different trace elements constituents in the sera of sheep are depicted in Table 3. Statistically, serum $\mathrm{Zn}$ conc. showed no variation $(\mathrm{P}>0.05)$ among different tehsils; however, that of $\mathrm{Cu}$ varied significantly $(\mathrm{P}<0.05)$ with maximum and minimum levels in sera of sheep from Multan city and Shujabad, respectively. Manganese and Co varied significantly $(\mathrm{P}<0.05)$ with their maximum and minimum serum levels in sheep from Multan Saddar and Jalalpur Pirwala, respectively.

It was found that only Mn showed significant correlation with the EPG of sheep reared in tehsil Shujabad; whereas, $\mathrm{Cu}, \mathrm{Zn}$ and Co showed insignificant results in all tehsils of district Multan. Table 4 presents correlation of the trace element profile of sheep sera with the mean EPG.

Table 1. Mean concentrations of selected trace element $(\mathrm{Zn}, \mathrm{Cu}, \mathrm{Mn} \& \mathrm{Co})$ in identified forages of district Multan, Punjab, Pakistan during spring 2016

\begin{tabular}{|c|c|c|c|c|}
\hline Plants & $\begin{array}{c}\mathrm{Zn} \\
(\mathrm{mg} / \mathrm{kg}) \\
\mathrm{Mean} \pm \mathrm{SE}\end{array}$ & $\begin{array}{c}\mathrm{Cu} \\
(\mathrm{mg} / \mathrm{kg}) \\
\mathrm{Mean} \pm \mathrm{SE}\end{array}$ & $\begin{array}{c}\text { Mn } \\
(\mathrm{mg} / \mathrm{kg}) \\
\text { Mean } \pm \text { SE }\end{array}$ & $\begin{array}{c}\text { Co } \\
(\mathrm{mg} / \mathrm{kg}) \\
\mathrm{Mean} \pm \mathrm{SE}\end{array}$ \\
\hline Digitaria sanguinalis & $31.46 \pm 0.42^{\text {bcd }}$ & $21.83 \pm 0.68^{\mathrm{bc}}$ & $36.75 \pm 0.39^{\mathrm{abc}}$ & $1.45 \pm 0.12^{\mathrm{abc}}$ \\
\hline Dactyloctenium aegyptium & $42.54 \pm 2.57^{\mathrm{a}}$ & $27.31 \pm 0.68^{\mathrm{a}}$ & $30.98 \pm 0.94^{\mathrm{d}}$ & $1.64 \pm 0.08^{\mathrm{ab}}$ \\
\hline Euphotia prostate & $36.25 \pm 0.41^{\mathrm{abcd}}$ & $16.44 \pm 0.53^{\mathrm{d}}$ & $25.75 \pm 0.20^{\mathrm{fg}}$ & $1.15 \pm 0.03^{\mathrm{cd}}$ \\
\hline Launaea nudicaulis & $28.34 \pm 0.35^{\mathrm{d}}$ & $19.47 \pm 0.22^{\mathrm{c}}$ & $37.30 \pm 0.53^{\mathrm{ab}}$ & $1.83 \pm 0.10^{\mathrm{a}}$ \\
\hline Ziziphus mauritiana & $46.33 \pm 1.15^{\mathrm{a}}$ & $22.47 \pm 0.72^{\mathrm{b}}$ & $31.12 \pm 0.72^{\mathrm{d}}$ & $1.50 \pm 0.26^{\mathrm{ab}}$ \\
\hline Alternanthera sessilis & $35.35 \pm 0.71^{\mathrm{abcd}}$ & $22.38 \pm 0.74^{\mathrm{b}}$ & $35.82 \pm 0.59^{\mathrm{bc}}$ & $1.12 \pm 0.09^{\mathrm{cd}}$ \\
\hline Convuvulus arvensisa & $39.82 \pm 0.40^{\mathrm{abc}}$ & $13.56 \pm 0.26^{\mathrm{e}}$ & $27.52 \pm 0.28^{\mathrm{ef}}$ & $0.92 \pm 0.12^{\mathrm{d}}$ \\
\hline Brachiaria raptens & $38.55 \pm 0.33^{\mathrm{abcd}}$ & $22.68 \pm 0.28^{\mathrm{b}}$ & $21.47 \pm 0.29^{\mathrm{h}}$ & $1.85 \pm 0.11^{\mathrm{a}}$ \\
\hline Cynodon dactylon & $41.57 \pm 0.21^{\mathrm{ab}}$ & $28.33 \pm 0.46^{\mathrm{a}}$ & $38.72 \pm 0.18^{\mathrm{a}}$ & $1.26 \pm 0.11^{\mathrm{bcc}}$ \\
\hline
\end{tabular}


Table 2. Mean concentrations of selected trace element $(\mathrm{Zn}, \mathrm{Cu}, \mathrm{Mn}$ and $\mathrm{Co})$ in forages from different tehsils of district Multan, Punjab, Pakistan during spring 2016

\begin{tabular}{|c|c|c|c|c|}
\hline Tehsils & $\begin{array}{c}\mathbf{Z n} \\
(\mathrm{mg} / \mathrm{L}) \\
\text { Mean } \pm \mathrm{SE}\end{array}$ & $\begin{array}{c}\mathrm{Cu} \\
(\mathrm{mg} / \mathrm{L}) \\
\mathrm{Mean} \pm \mathrm{SE}\end{array}$ & $\begin{array}{c}\text { Mn } \\
(\mathrm{mg} / \mathrm{L}) \\
M e a n \pm S E\end{array}$ & $\begin{array}{c}\mathrm{Co} \\
(\mathrm{mg} / \mathrm{L}) \\
\text { Mean } \pm \mathrm{SE}\end{array}$ \\
\hline Multan Sadar & $31.75 \pm 2.37^{\mathrm{a}}$ & $24.95 \pm 4.05^{\mathrm{a}}$ & $29.60 \pm 6.39^{a}$ & $1.630 \pm 0.158^{\mathrm{a}}$ \\
\hline Multan City & $35.22 \pm 6.41^{\mathrm{a}}$ & $22.53 \pm 5.59^{\mathrm{a}}$ & $31.65 \pm 5.51^{\mathrm{a}}$ & $1.345 \pm 0.383^{\mathrm{a}}$ \\
\hline Jalalpur Pirwala & $39.24 \pm 3.63^{\mathrm{a}}$ & $21.08 \pm 6.97^{\mathrm{a}}$ & $31.44 \pm 4.71^{\mathrm{a}}$ & $1.227 \pm 0.372^{\mathrm{a}}$ \\
\hline Shujabad & $40.53 \pm 4.56^{\mathrm{a}}$ & $22.48 \pm 4.85^{\mathrm{a}}$ & $28.90 \pm 7.70^{\mathrm{a}}$ & $1.590 \pm 0.265^{\mathrm{a}}$ \\
\hline
\end{tabular}

Mean sharing similar letters in a column are statistically insignificant $(\mathrm{P}>0.05)$.

Table 3. Mean concentrations of selected trace element $(\mathrm{Zn}, \mathrm{Cu}, \mathrm{Mn}$ and $\mathrm{Co})$ in serum of grazing sheep from different tehsils of district Multan, Punjab, Pakistan during spring 2016

\begin{tabular}{|c|c|c|c|c|}
\hline Tehsils & $\begin{array}{c}\mathrm{Zn} \\
(\mathrm{mg} / \mathrm{L}) \\
\mathrm{Mean} \pm \mathrm{SE}\end{array}$ & $\begin{array}{c}\mathrm{Cu} \\
(\mathrm{mg} / \mathrm{L}) \\
\mathrm{Mean} \pm \mathrm{SE}\end{array}$ & $\begin{array}{c}\text { Mn } \\
(\mathrm{mg} / \mathrm{L}) \\
\text { Mean } \pm \text { SE }\end{array}$ & $\begin{array}{c}\mathrm{Co} \\
(\mathrm{mg} / \mathrm{L}) \\
\mathrm{Mean} \pm \mathrm{SE}\end{array}$ \\
\hline Multan Sadar & $0.93 \pm 0.17^{\mathrm{a}}$ & $0.62 \pm 0.09^{b}$ & $0.16 \pm 0.09^{\mathrm{a}}$ & $0.07 \pm 0.03^{b}$ \\
\hline Multan City & $0.97 \pm 0.20^{\mathrm{a}}$ & $0.91 \pm 0.20^{\mathrm{a}}$ & $0.14 \pm 0.04^{\mathrm{ab}}$ & $0.11 \pm 0.04^{\mathrm{a}}$ \\
\hline Jalalpur Pirwala & $0.83 \pm 0.24^{\mathrm{b}}$ & $0.86 \pm 0.19^{\mathrm{a}}$ & $0.12 \pm 0.04^{\mathrm{b}}$ & $0.06 \pm 0.02^{\mathrm{c}}$ \\
\hline Shujabad & $0.92 \pm 0.17^{\mathrm{a}}$ & $0.61 \pm 0.18^{b}$ & $0.13 \pm 0.04^{\mathrm{b}}$ & $0.06 \pm 0.02^{\mathrm{c}}$ \\
\hline
\end{tabular}

Mean sharing similar letters in a column are statistically insignificant $(\mathrm{P}>0.05)$

Table 4. Correlation of egg per gram with trace element profile of sheep reared on grazing areas of different tehsils of district Multan

\begin{tabular}{llcccc}
\hline \multicolumn{1}{c}{ Tehsils } & & Zn & Cu & Mn & Co \\
\hline Multan Sadar & Pearson Correlation & -0.037 & 0.128 & -0.194 & -0.006 \\
& Sig. (2-tailed) & 0.842 & 0.494 & 0.295 & 0.972 \\
Multan City & Pearson Correlation & -0.012 & 0.027 & 0.065 & 0.053 \\
& Sig. (2-tailed) & 0.940 & 0.869 & 0.694 & 0.750 \\
\multirow{2}{*}{ Shujalpur Pirwala } & Pearson Correlation & -0.198 & 0.224 & -0.097 & -0.102 \\
& Sig. (2-tailed) & 0.234 & 0.176 & 0.562 & 0.542 \\
& Pearson Correlation & 0.011 & -0.060 & -0.312 & 0.105 \\
& Sig. (2-tailed) & 0.937 & 0.663 & 0.019 & 0.441 \\
\hline
\end{tabular}

\section{DISCUSSION}

Gastrointestinal parasitism is one of the major problems of livestock population round the world. Determination of frequency distribution of GI parasites helps to make strategies for their control. Our results of prevalence of GI parasitism are not different from those reported elsewhere by Raza et al. (2009) and Khan et al. (2010). Higher prevalence of GI parasites was determined by Gadahi et al. (2009), however, Rizwan et al. (2017, 2019) recorded lower prevalence. Variable results of GI parasites might be due to environmental conditions. In dry condition, prevalence of GI parasites was reported lower (Khan et al., 2010) as compared to wet condition (Radostits et al., 2007). However, year round grazing of livestock in contaminated pasture is responsible for persistent infection of GI parasites (Kumar et al., 2013). Scientists also observed that the chances of parasitic infections were more in sedentary flocks (Waller, 2004). Husbandry practices, stress conditions, long travelling, gestation and environmental conditions are also responsible for variable prevalence of GI parasites.

Results regarding age-wise prevalence are in line with those of Khan et al. (2008) and not in line with those of Qamar (2009) and Khan et al. (2010). However, Abunna et al. (2009) found insignificant results in different age groups. This variation might be due to low level of immunity in youngstock as compared to older animals or persistent exposure with parasites during grazing in the contaminated areas. It has been reported that weaned lambs and yearlings were more prone to parasitic infection (Radostits et al., 2007), while a significant immunity develops with age (Urquhart et al., 1996). Grazing in low contaminated pastures and provision of supplements like green wheat, barley grains and Barseem will be helpful to control or lower the prevalence of GI parasites (Kumar et al., 2013). Among 
breeds, a significant difference of GI parasites was recorded by Abunna et al. (2009), while Urquhart et al. (1996) recorded insignificant results. The susceptibility of various breeds to GI parasites varies and is genetically determined.

Similar results regarding prevalence of GI parasites in different sex were in line with those of Raza et al. (2009) while not in agreement with those of Idris et al. (2012) and Urquhart et al. (1996). Findings of Qamar (2009) indicated that both sexes are equally susceptible to GI parasitic infection. It has been reported that hormonal changes in both sexes are responsible for severity of parasitic infection e.g. males are more prone to parasitic infection due to androgen while in female estrogens stimulate the immune response which increases the resistance against infection (Urquhart et al., 1996). In females, higher prevalence might be due to stress and hormonal changes during pregnancy and lactation period. Availability of insufficient diet and enhanced grazing during these periods may also increase the chances of infection (Raza et al., 2009).

Forage analysis is a routine practice for trace elements determination (McDowell \& Arthington, 2005) because trace element constituents of consumed forages reflect the mineral status of the grazing sheep. Level of $\mathrm{Zn}$ among the prevalent forage species in Multan has a close resemblance with that of earlier reports (Ramirez et al., 2001; Hussain \& Durrani, 2008; Habib et al., 2013); however, is partially in agreement with other reports (Khan et al., 2004; 2005; 2006). Zinc requirements for grazing livestock have been suggested between 20 and 40 $\mathrm{mg} / \mathrm{kg}$ (McDowell et al., 1983; Ndebele et al., 2005). Its deficiency has been reported in ruminants grazing forages low in $\mathrm{Zn}$ or high in compounds like $\mathrm{Cd}, \mathrm{Fe}, \mathrm{Mg}, \mathrm{Mn}$, $\mathrm{Mo}$ and $\mathrm{S}$, which interact $\mathrm{Zn}$ utilizations in ruminants (Ndebele et al., 2005). Aregheore, (2002) concluded that forages mineral composition depends on soil type, plant species, plant age, variety, utilization of fertilizers, seasonality, and grazing pressure. Lower levels of $\mathrm{Zn}$ in different native forages have been observed (Sher et al., 2011; Ahmad et al., 2012).

Copper levels of the identified forages are well supported by different scientists who reported the similar values in forages consumed by livestock (Ramirez et al., 2001; Khan et al., 2004). Rangeland forages may contain lower level than recommended dietary requirements for livestock (Hussain \& Durrani, 2008; Sher et al., 2011; Habib et al., 2013). Low levels of $\mathrm{Cu}$ in forages have been reported in Turkey (Or et al., 2005), Greece (Mountousis et al., 2009; Silvanus et al., 2014) and India (Soni et al., 2014). One of the factors that may affect forage $\mathrm{Cu}$ values is low soil $\mathrm{pH}$ which increases iron solubility resulting into diminished/supressed $\mathrm{Cu}$ absorption by the plants. Low $\mathrm{Cu}$ levels in forages may also be attributed to the presence of antagonist elements like Mo, S and Ca (McDowell \& Arthington, 2005).
Manganese levels in forages consumed by small ruminants of the study district are similar to those previously reported by Mountousis et al. (2009) and Soni et al. (2014). Relatively higher Mn levels in forage species have been noted by Khan et al. (2006), Hussain \& Durrani (2008) and Khan et al. (2008).

Higher trend of forage Mn constituent has also been reported in Mexico (Ramirez et al., 2001), Pakistan (Habib et al., 2013), Greece (Silvanus et al., 2014) and Kenya (Udiba et al., 2014). Forages consumed by livestock containing low levels of $\mathrm{Mn}$ have also been reported (Sher et al., 2011). Cobalt deficiency is considered the most severe mineral deficiency in the grazing livestock (McDowell et al., 1984) and its uptake by plants is dependent on $\mathrm{Co}$ and $\mathrm{Mn}$ conc. in soils. Higher soil $\mathrm{Mn}$ conc. depresses Co uptake in forages (Khan et al., 2005).

The best mean to find the conc. of minerals in animals is blood analysis (Mills, 1987) and generally animal blood mineral concentration is less than $2 \mathrm{ppm}$ (Suttle, 2010). The need of minerals in animal body depends on different factors such as age, sex and breed (NRC, 2001). The difference in $\mathrm{Zn}$ availability in blood of animal may be due to many reasons such as feed intake, age of animal or any stress (Ishag et al., 2014). Zinc alteration in animal blood can also occur due to reduced growth and presence of inhibitors in animal feed intake (Mills, 1981). Cu conc. in sheep having parasitic load was found to be lower than in sheep free from parasites (Ortolani et al., 1993). Ishag et al. (2014), declared deficient $\mathrm{Cu}$ levels in different ages, sex, breeds and feed stuffs. Some minerals like Se have higher tendency to be absorbed and retained in sheep body which are being fed on concentrate instead of fodder (Koening et al., 1997). Sera of sheep population of district Chakwal showed normal level of $\mathrm{Cu}$, Mo and Se while level of $\mathrm{Zn}$ was marginally deficient. However, level of $\mathrm{Co}$ and $\mathrm{Mn}$ were higher than the normal ranges (Qudoos et al., 2017).

To assess whether deworming is required in a herd, Eggs per gram (EPG) of the faeces of animals is the best mean to reveal the parasitic burden of the animal. Our results correlate with the findings of Tramboo et al. (2015), and somehow also relate with those of Roy et al. (2013). Similarly, increased EPG values with different parasites were reported; whereas, Martínez-Valladares et al. (2013) results revealed lower values of EPG. These differences may be due to the difference in sample size, suppression of harmful larvae, reduction of egg production or improper preservation of faecal samples (Das et al., 2011). Moreover EPG value is higher in summer than winter revealing weather effect on EPG (Ahmed, 2002). There are other factors which influence EPG including: age (Idika et al., 2012) and sex (Roy et al., 2013). The difference in EPG value of these tehsils 
may be due to the presence of different parasites in these areas (Fakae, 1990).

Trace elements work as cofactor for various enzymes and as part of different tissues (Erdoğan et al., 2002, Anonymous, 2016). Adequate levels of trace element in animals maintain the functions of immune system which ultimately reduces the chances of parasitic infection (McClure, 2008). Aypak et al. (2016) found that trace element like $\mathrm{Ca}, \mathrm{P}, \mathrm{Mn}, \mathrm{Cu}, \mathrm{Zn}$ in serum had insignificant association with the burden of GI parasites however, Cd showed significant association. In a study conducted by Qudoos et al. (2017), all the trace element $(\mathrm{Cu}, \mathrm{Mo}, \mathrm{Se}, \mathrm{Zn}$, Mn, Co) showed insignificant correlation with EPG of naturally infected sheep population of Chakwal district. While, Rizwan et al. (2019) reported that sheep having high level of $\mathrm{Zn}$ and $\mathrm{Cu}$ in sera showed lower burden of GI parasites. Animals deficient in Co are less immune to parasites than animals having adequate amount of Co. Lambs having Co deficiency showed higher faecal egg counts, less immune response and lower vitamin $\mathrm{B}_{12}$ production than the lambs provided with higher amount of Co (Schafer et al., 2015).

The correlation of $\mathrm{Cu}$ level in blood with the burden of parasitic infection (Trichostrongylus axei and T. colubriformis) of sheep showed inverse relationship (Hucker and Yong, 1986). Similarly, lower levels of serum $\mathrm{Zn}$ and $\mathrm{Cu}$ were reported in sheep population infected with Trichostrongylus sp. (Abdellall, 1991) and H. contortus (Silva et al., 1978). However, Siddiqua et al. (1989) reported a positive association between decrease level of iron and EPG of faeces. In another study, serum of experimentally infected sheep with $T$. colubriformis showed lower level of Zn (Symons, 1983). Schafer et al. (2015) reported that higher level of $\mathrm{Cu}$ and Se in sheep did not show any reduction in burden of $H$. contortus.

In natural grazing system, animals containing higher level of $\mathrm{Zn}$ and $\mathrm{Cu}$ showed low level of parasitic burden. The results of the present study provide useful data on the trace element profile of flora of the study district to provide preventive management strategy against GI parasites for the grazing sheep population. However, it is not a final conclusion that the higher level of $\mathrm{Mn}$ is the only responsible factors for lower EPG because there is a possibility that the grazing forages may contain some elements which are effective against GI parasites. It is recommended to determine the specific contents in forages along with trace element which are effective for the control of GI parasites. There is also need of a comprehensive study to determine the possible mechanism of trace element against GI parasites and development of immunity.

Acknowledgments: Authors are very thankful to the Higher Education Commission (HEC), Islamabad, Pakistan for the financial support of this study under the project No.20-2666/NRPU/R\&D/HEC/12/6974, entitled "Phytotherapy: An Easy and Economic Way to Cure the Gastro-intestinal Parasites in Sheep".

\section{REFERENCES}

Abunna, F., B. Tsedeke, B. Kumsa, A. Megersa, and A. Regassa (2009). Abomasal nematodes: prevalence in small ruminants slaughtered at Bishooftu Town, Ethiopia. Int. J. Vet. Med.7: 1937-8165.

Abdellall, T.S. (1991). Haematological and biochemical studies on the efficacy of synanthic againts gastrointestinal parasites in sheep. Assiut Vet. Med. J. 24 (48): 197-203.

Ahmad, K., Z.I. Khan, M. Ashraf, and A. Ejaz (2012). Appraisal of temporal variation in soil and forage iron and zinc in a pasture under semi-arid environmental conditions. Pakistan J. Bot. 44: 157-160.

Ahmed, M.A.A. (2002). Gastrointestinal (nematode) infections in small ruminants: Epidemiology, anthelmintic efficacy and the effect of wattle tannins. M.Sc. Thesis, School of Agricultural Sciences and Agribusiness, University of KwaZulu-Natal, Pietermaritzburg, South Africa.

Anonymous, (2016). Anne Sütüne En Yakın Süt Hayvan Sütü Hangisidir-Keçi Sütü Yararları. Available from: URL: http://www.sagligimiza.com/tag/ keci-sutu-faydalari, date of access: 22.11.2016.

Aregheore, E.M. (2002). Voluntary intake and digestibility of fresh, wilted and dry Leucaena (Leucaena leucochepala) at four levels to a basal diet of guinea grass (panicum maximum). Asian-Aust. J. Anim. Sci. 15: 1139-1146.

Aypak, S.U., S. Aypak, H. Voyvoda, G Güven, E.D. Fidan, G. Tosun, M. Gültekin, E. Şimşek, and A.G. Güler, (2016). Comparative analysis of serum mineral levels and parasite load in goats naturally infected with gastrointestinal nematodes. Turkiye. Parazitol. Derg. 40: 141-6

Bhushan, B., N. Saxena, and P.N. Saxena (2010). Betacyfluthrin induced histochemical alteration in the liver of the albino rat. Scand. J. Lab. Anim. Sci. 37: 61-66.

Das, G., T. Savas, F. Kaufmann, A. Idris, H. Abel, and M. Gauly (2011). Precision, repeatability and representative ability of faecal egg counts in Heterakis gallinarum infected chickens. Vet. Parasitol.183: 87-94.

Erdoğan, S., Y. Ergün, Z. Erdoğan, and T. Kontas, (2002). Hatay bölgesinde yetiştirilen koyun ve keçi serumlarında bazı mineral madde düzeyleri. Tük. J. Vet. Anim. Sci. 26: 177-82.

Fakae, B.B. (1990). Seasonal changes and hypobiosis in Haemonchus contortus infection in the West 
African Dwarf sheep and goats in the Nigerian derived Savanna. Vet. Parasitol. 36: 123-130.

Gadahi, J.A., M.J. Arshed, Q. Ali, S.B. Javaid, and S.I. Shah (2009). Prevalence of gastrointestinal parasites of sheep and goat in and around Rawalpindi and Islamabad, Pakistan. Vet. World 2: 51-53.

Gathuma, J.M., J.M. Mbaria, J. Wanyama, H.F.A. Kaburia, L. Mpoke, J.N. Mwangi, Samburu, and T. Healers (2004). Efficacy of Myrsine africana, Albizia anthelmintica and Hilderbrantia sepalosa herbal remedies against mixed natural sheep helminthosis in Samburu district, Kenya. J. Ethnopharmacol. 91: 7-12.

Habib, G., M. Saleem, and A. Hameed (2013). Mineral composition of local tree leaves for feeding sheep and goats in Kohat district of Khyber Pakhtunkhwa. Sarhad. J. Agric.29: 97-103.

Hucker D.A., and W.K. Yong (1986). Effects of concurrent copper deficiency and gastrointestinal nematodiasis on circulating copper and protein levels, liver copper and bodyweight in sheep. Vet. Parasitol. 19: 67-76.

Hussain, F., and M.J. Durrani (2008). Mineral composition of some range grasses and shrubs from Harboi rangeland Kalat, Pakistan. Pakistan J. Bot. 40: 2513-2523.

Idika, I.K., C.N. Iheagwam, C.N. Ezemonye, and C.O. Nwosu (2012). Gastrointestinal nematodes and body condition scores of goats slaughtered in Nsukka, Nigeria. Nig. Vet. J. 33: 440-447.

Idris, A., M. Eva, S. Birgit, and G. Matthias (2012). Gastrointestinal nematode infections in German sheep. Parasitol. Res. 4: 1453-1459.

Ishag, H.I., I.G. Ibrahim, A.M. Shamat, A. Aisha, and S.H. Eisa (2014). Mineral profile of sheep and goats grazed natural pasture in Nyala locality, Western Sudan. J. Agric. Vet. Sci. 15: 53-61.

Khan, M.N., M.S. Sajid, M.K. Khan, Z. Iqbal, and A. Hussain (2010). Gastrointestinal helminthiasis: prevalence and associated determinants in domestic ruminants of district Toba Tek Singh, Punjab, Pakistan. Parasitol. Res. 107: 787-794.

Khan, M.N., M.S. Sajid, H.M. Rizwan, A. Qudoos, R.Z. Abbas, M. Riaz and M.K. Khan (2017). Comparative efficacy of six anthelmintic treatments against natural infection of fasciola species in sheep. Pakistan Vet. J. 37(1): 65-68.

Khan, Z.I., A. Hussain, M. Ashraf, E.E. Valeem, and I. Javed (2005). Evaluation of variation in soil and forage micro-mineral concentrations in a semiarid region of Pakistan. Pakistan J. Bot. 37: 921-931.

Khan, Z.I., A. Hussain, M. Ashraf, and L.R. McDowell (2006). Mineral status of soils and forages in southwestern Punjab-Pakistan: Micro-minerals.
Asian-Aust. J. Anim. Sci. 19: 1139-1147.

Khan, Z.I., A. Hussain, M. Ashraf, M.Y. Ashraf, E.E. Valeem, and M.S. Ahmad (2004). Soil and forage (Trace elements) status of a grazing pasture in the semiarid region of Pakistan. Pakistan J. Bot. 36: 851-856.

Khan, Z.I., M. Ashraf, K. Ahmad, I. Javed, and E.E. Valeem (2008). A comparative study on mineral status of blood plasma of small ruminants and pastures in Punjab, Pakistan. Pakistan J. Bot. 40: 1143-1151.

Koening, K.M., L.M. Rode, R.D. Cohen, and W.T. Buckley (1997). Effects of diet and chemical forms of selenium on blood, milk and casein selenium concentrations in grazing cow. J. Dairy Sci. 82: 429-437.

Kumar, N., T.K.S. Rao, A. Varghese, and V.S. Rathor (2013). Internal parasite management in grazing livestock. J. Parasitic Dis. 37(2): 151-157.

Mahima, Rahal, A., Deb, R., Latheef, S.K., Samad, H.A., Tiwari, R., Verma, A.K., Kumar, A. and Dhama, K. (2012). Immunomodulatory and therapeutic potentials of herbal, traditional / indigenous and ethnoveterinary medicines. Pakistan J. Biol. Sci. 15(16): 754-774.

Martínez-Valladares, M., D. Robles-Pérez, J.M. Martínez-Pérez, C. Cordero-Pérez, M.D.R. Famularo, N. Fernández-Pato, C. GonzálezLanza, L. Castañón-Ordóñez, and F.A. RojoVázquez (2013). Prevalence of gastrointestinal nematodes and Fasciola hepatica in sheep in the northwest of Spain: Relation to climatic conditions and/or man-made environmental modifications. Parasite Vec. 6: 282-290.

McClure S.J. (2008). How minerals may influence the development and expression of immunity to endoparasites in livestock. Parasite immunol. 30: $89-100$

McDowell, L.R., and J.D. Arthington (2005). Minerals for Grazing Ruminants in Tropical Regions, $5^{\text {th }}$ Ed.University of Florida, Gainesville, USA. pp: 86.

McDowell, L.R., H. Conard, G.L. Ellis, and L.K. Loosli (1983). Minerals for grazing ruminants in tropical regions. Extension Bulletin, 1149. Animal Science Department, University of Florida, Gainsville, USA.

McDowell, L.R., J.H. Conrad, and G.L. Ellis (1984). Mineral deficiencies and imbalances and their diagnosis. In: Gilchrist, F.M.C. Mackie, R.I. (Ed.). Symposium on Herbivores Nutrition in Sub-Tropics and Tropics-Problems and Prospects. South Africa, Craighall. pp: 67-88.

Miller, J.E., M. Bahirathan, S.L. Lemarie, F.G. Hembry, M.T. Kearney, and S.R. Barras (1998). Epidemiology of gastrointestinal nematode 
parasitism in Suffolk and Gulf Coast native sheep with special emphasis on relative susceptibility to Haemonchus contortus infection. Vet. Parasitol. 74: 55-74.

Mills, C.F. (1981). Some outstanding problems in the detection of trace element deficiency diseases. Philos. Trans. R Soc. Lond. Biol. Sci. 294: 199.

Mills, C.F. (1987). Biochemical and physiological indicators of mineral status in animals: Copper, cobalt and zinc. J. Anim. Sci. 65: 1702-1711.

Mountousis, I., K. Papanikolaou, G. Stanogias, G., Ch. Roukos, F. Chatzitheodoridis, and A. Papazafiriou (2009). Mineral content of the herbage material in pastures of Mt. Varnoudas NW Greece. Agron. Res. 7: 837-846.

Ndebele, N., J.P. Mtimuni, I.D.T. Mpofu, S. Makuza, and P. Mumba (2005). The status of selected minerals in soils, forage and beef cattle tissues in a semi-arid region of Zimbabwe. Trop. Anim. Health Prod. 37: 381-393.

NRC (2001). Nutrient Requirements of Domestic Animals. Nutrient Requirements of Dairy Cattle, $7^{\text {th }}$ revised ed. National Academy of Sciences, Washington, DC, USA.

Or, M.E., A. Kayar, A.R. Kiziler, C. Parkan, R. Gönül, B. Barutçu, and H.T. Dodurka (2005). Determination of levels of some essential (iron, copper, zinc) and toxic (lead, cadmium) metals in the blood of sheep and in samples of water, plants and soil in Northwest Turkey. Vet. Arhiv. 75: 359-368.

Ortolani, E., D. Knox, F. Jakson, R. Coop, N.F. Suttle, M. Anke, D. Meissner, and C.F. Mills (1993). Abomasum parasitism lowers liver $\mathrm{Cu}$ status and influences the CuXMOXS antagonism in lambs. Trace element in man and animals. TEMA 8: Proc $8^{\text {th }}$ Intl. Symp. on Trace Elements in Man and Anim. pp: 331-332.

Qamar, M.F. (2009). Epidemiology, sero-diagnosis, economic losses and control of haemonchosis in sheep and goats. Ph. D. Thesis, Dept. of Parasitology, Univ. of Vet. and Animal Sc., Lahore, Pakistan. p. 63-113.

Qudoos, A., M.N. Khan, M.S. Sajid, and G. Muhammad (2017). Correlation of trace mineral profiles with gastrointestinal worm burden in rangeland sheep of Chakwal District, Punjab, Pakistan. Int. J. Agric. Biol. 19: 140-144.

Radostits, O.M., C.C. Gay, D.C. Blood, and K.W. Hinchclift (2007). Veterinary Medicine. A Text Book for the Diseases of Cattle, Sheep, Pigs, Goats and Horses, 2007; $10^{\text {th }}$ Ed. Bailliere Tindall, London, UK.

Ramirez, R.G., G.F.W. Haenleinb, M.A. and NunezGonzaleza (2001). Seasonal variation of macro and trace mineral contents in 14 browse species that grow in northeastern Mexico. Small Rum. Res. 39: 153-159.

Raza, M.A., S. Murtaza, H.A. Bachaya, G. Dastager, and A. Hussain (2009). Point prevalence of haemonchosis in sheep and goats slaughtered at Multan abattoir. J. Anim. Plant Sci.19: 158-159.

Rizwan, H.M., M.S. Sajid, Z. Iqbal and M. Saqib (2017). Point prevalence of gastrointestinal parasites of domestic sheep (Ovis aries) in district Sialkot, Punjab, Pakistan. J. Anim. Plant Sci. 27(3): 803808.

Rizwan, H.M., M.S. Sajid, Z. Iqbal and M. Saqib (2019). Association of phytomineral with gastrointestinal parasites of grazing sheep in Sialkot district, Punjab, Pakistan. Pakistan J. Agric. Sci. 56(2): 459-468.

Rizwan, H.M, M.S. Sajid, H. Abbas, M.F. Qamar, Q. Akram and M. Maqbool (2019a). Epidemiology and Control of Congo Fever in Sacrificial Animals of Pakistan. Vet. Sci. Res. 01 (02): 1824.

Roy, M., P.K. Senapati, S. Roy, and D. Nandi (2013). Factors affecting variability of resistance in garole sheep naturally infected with Haemonchus contortus. Explor. Anim. Med. Res. 3: 57-64.

Samanta, A., and G. Samanta (2002). Mineral profile of different feed and fodders and their effect on plasma profile in ruminants of West Bengal. Ind. J. Anim. Nutr. 19: 278-281.

Schafer, A.S, M.L.R. Leal, M.B. Molento, A.R. Aires, M.M.M.F. Duarte, F.B. Carvalho, A.A. Tonin, L. Schmidt, E.M.M. Flores, R.T. Franca, T.H. Grando, A.P. Minho, A. Krause, A.Q. Antoniazzi, and S.T.A. Lopes (2015). Immune response of lambs experimentally infected with Haemonchus contortus and parenterally treated with a combination of zinc and copper. Small Rum. Res. 123: 183-188

Schork, M.A., and R.D. Remington (2010). Statistics with Applications to the Biological and Health Sciences. $3^{\text {rd }}$ Ed, Lexington, K.Y. USA.

Sher, Z., F. Hussain, and L. Badshah (2011). Micromineral contents in eight forage shrubs at three phenological stages in a Pakistan's rangeland. African J. Plant Sci. 5: 557-564.

Siddiqua, A., M.A. Mannan, and M.A. Hussain (1989). Some biochemical studies in the blood of goats naturally infected with intestinal parasites. Ind. Vet. J. 66: 502-4.

Silva, R.M., J.M. Ferreira-Neto, and I.B.M. Sampa1o (1978). The influence of diet and gastrointestinal parasites on serum copper and zinc in sheep (Abst). Arq. Esc. Vet. Univ. Minas Gerais. 30: 261-74. 
Silvanus, S.K., N. Veronica, N. Hudson, J. Isaac, and O. Fredrick (2014). Assessment of mineral deficiencies among grazing areas in Uasin Gishu County, Kenya. Int. J. Nut. Food Sci. 3: 44-48.

Soni, A., K. Kumar, and R. Mathur (2014). Mineral status of some common vegetation available in Jodhpur district of Rajasthan. Int. J. Plant Anim. Environ. Sci. 4: 359-365.

Soulsby, E.J.L. (1982). Helminths, Arthopods and Protozoa of Domesticated Animals. $7^{\text {th }} \mathrm{Ed}$. ELBS, Baillere Tindall, London, UK.

Suttle, N.F. (2010). Mineral Nutrition of Livestock. $4^{\text {th }}$ Ed. CABI Publishing, USA.

Symons, L.E.A. (1983). Plasma zinc innapetencein sheep infected with Trichostrongylus colubriformis. J. Comparative Patho. 93: 547-50.

Tiwari, R., S.K. Latheef, I. Ahmed, H.M.N. Iqbal, M.H. Bule, K. Dhama, H.A. Samad, K. Karthik, M. Alagawany, M.E.A. El-Hack, M.I. Yatoo, and M.R. Farag (2018). Herbal Immunomodulators A Remedial Panacea for Designing and Developing Effective Drugs and Medicines: Current Scenario and Future Prospects. Curr. Drug Metab. 19(3): 264-301.
Tramboo, S.R., R.A. Shahardar, I.M. Allaie, Z.A. Wani, and M.S. Bushra (2015). Prevalence of gastrointestinal helminth infections in ovine population of Kashmir Valley. Vet. World 8: 1199-1204.

Udiba, U.U., M.O. Odey, A.H. Jibril, B. Gauje, O. Sikemi, A.M. Sule, H.A. Mohammad, and M. Abdullah (2014). Manganese and magnesium status of forage grasses and its implications for grazing animals, Dareta Village, Zamfara, Nigeria. Int. Res. J. Pure Appl. Chem. 4: 203212.

Urquhart, G.M., J. Armour, J.L. Duncan, and F.W. Jennings (1996). Veterinary Parasitology. $2^{\text {nd }}$ Ed. The Faculty of Veterinary Medicine, The University of Glasgow, Scotland. p. 131-133.

Waller, P.J. (2004). Management and control of nematode parasites of small ruminants in the face of total anthelmintic failure. Trop. Biomed. 21: 713 .

Wolstenholme, A.J., I. Fairweather, R. Prichard, G. von Samson-Himmelstjerna, and N.C. Sangster (2004). Drug resistance in veterinary helminths. Trends Parasitol. 20: 469-476. 